\title{
Progressive Disseminated Superficial Actinic Porokeratosis: a Case Report with a Family History in Three Generations
}

\author{
Milica STEPANOVIĆ ${ }^{1}$, Mirjana PARAVINA², Dragica MARKOVIĆ ${ }^{3}$, Danica JANJIĆ SPASIĆ ${ }^{1}$ \\ ${ }^{1}$ Special Hospital for Rehabilitation Prolom Spa, AD Planinka Kuršumlija, Serbia \\ ${ }^{2}$ Faculty of Medicine, University of Niš, Serbia \\ ${ }^{3}$ Prokuplje Primary Health Care Center, Serbia
}

*Correspondence: Mirjana Paravina, E-mail: mirjanaparavina@gmail.com

DE GRUYTER

UDK 616.5-001.15-056.7 OPEN

\begin{abstract}
Disseminated superficial actinic porokeratosis is the most common form of porokeratosis in adults, which develops in the third or fourth decade of life, but may also occur later or earlier, more frequently in females, particularly in countries with high sun exposure. Lesions are numerous, uniform, superficial with central atrophy, demarcated by a distinct peripheral ridge, and usually found on sun exposed areas or elsewhere. The disease is inherited as an autosomal dominant condition.

We present a 57-year-old retired woman. Her initial skin changes, affecting the face, developed in her thirties, and they have not changed their features since. In the following years, changes developed on the extensor surface of her arms and legs, with more prominent erythema, and then also on other parts of the body, including palms and soles, presenting as dark brown pigmented patches. Her mother had similar changes, and her daughter, who lives abroad, also has them.

On examination, the patient presented with facial lesions, patches 2-3 $\mathrm{mm}$ wide, with peripheral hyperpigmentation and a pale center. There were multiple, 2-3 mm wide, dark brown lesions on the extremities and trunk. The lesions were either flat or with atrophic center with darker filiform corneal rim. Pathohistolgical examination revealed a "cornoid lamella", which is pathognomonic for the diagnosis of porokeratosis. Auxiliary diagnostic methods were also used dermoscopy and Gentian violet staining.

The patient was advised to avoid sun exposure and to apply photoprotective sunscreens.

In conclusion, this is a case report of a disseminated superficial actinic porokeratosis that affected three generations of a family. Our patient developed lesions on palms and soles as well. A review of available world literature shows that this is the second case report of disseminated superficial actinic porokeratosis with palmoplantar involvement.
\end{abstract}

\section{Key words}

Porokeratosis + genetics; Keratosis, Actinic; Keratoderma, Palmoplantar; Disease Progression; Risk Factors

$\mathrm{P}_{\mathrm{d}}$ orokeratosis $(\mathrm{P})$ is a heterogeneous, genetically determined keratinization disorder, characterized by circular lesions with central atrophy and distinct peripheral ridges, on histology corresponding to a "cornoid lamella" (1). Depending on the size, localization and number of lesions, there are several subtypes of porokeratosis (2). Since 1893, when Mibelli described the "classic" type of porokeratosis, which was named porokeratosis of Mibelli after him (3), and Respighi described the disseminated superficial type of the disease, several new forms have been described (4-7). These are: 1) porokeratosis of Mibelli (PM); 2) linear porokeratosis (LP); 3) disseminated superficial porokeratosis (DSP); 4) disseminated superficial actinic porokeratosis (DSAP); 5) disseminated palmoplantar porokeratosis (DPPP); 6) punctate palmoplantar porokeratosis (PPPP) and 7) porokeratosis ptychotropica $(8,9)$. 
Also, facial, giant, reticular, hypertrophic veruccous morphologial forms of porokeratosis have been distinguished (10). PM, LP, PPPP are localized, and DSAP, DSP and DPPP are disseminated types of porokeratosis.

The term DSAP was suggested by Chernosky and Freeman in 1967 (11). This is the most common type of porokeratosis, usually occurring in the third or fourth decade of life, but depending on the underlying cause, it may also occur later or earlier (12). It is more common in females, particularly in countries with long periods of sunshine. At least $50 \%$ of patients experience exacerbations after exposure to sun or artificial light. Although lesions affect sun exposed areas, only $15 \%$ of patients have facial lesions (10). However, lesions may also occur on parts of the body not exposed to light. The initial lesions are keratotic papules, while marked annular lesions with atrophic center and peripheral keratotic ridge, and "cornoid lamella" which is characteristic for all types of porokeratosis, develop later.

We report a case of a patient presenting with a severe DSAP, in whom initial skin changes developed 27 years earlier, and in 1990, her and her mother's case reports were presented at the Dermatological Days in Paris (13).

\section{Case report}

We present a 57-year-old female, a retired nurse who pursues farming, with a history of facial skin lesions which appeared at the age of thirty. One year later, after seaside sunbathing, lesions spread over the extensor sides of her forearms, upper arms, and on the legs below the knee. They were more palpable

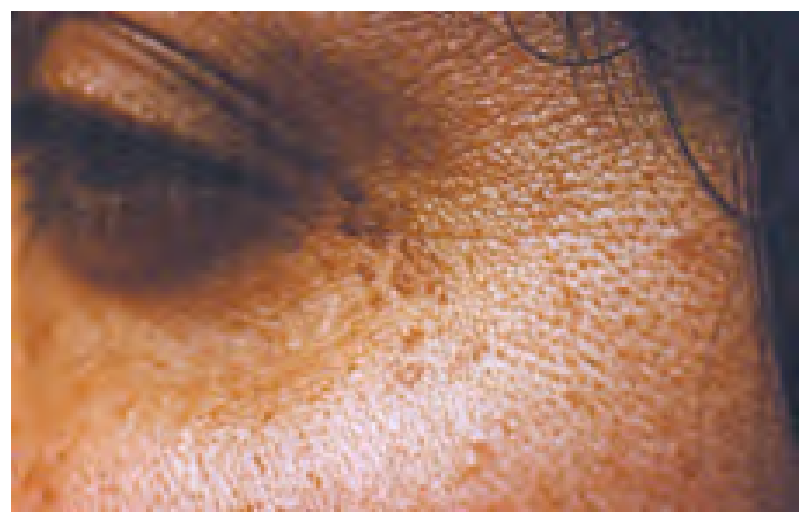

Figure 1. Facial lesions in 1990 than visible at the time. In the years to come, new lesions developed, the size of about $2-5 \mathrm{~mm}$. The patient did not suffer from any other diseases.

In 2001, she had hepatitis B. She also developed gonarthrosis, hypertension, as well as ptosis; she was regularly taking antihypertensive drugs. The patient's mother had the same skin condition, high blood pressure and coxarthrosis. Her daughter developed spot-like darker "stains" around the mouth, while her son was healthy.

\section{Dermatological status}

The skin condition in 1990: embarrassing lesions/ blotches, 2-3 $\mathrm{mm}$ wide, hyperpigmented on the periphery and paler in the center appeared on the face (Figure 1); lesions on the trunk (Figures 2 and 3) and extremities (Figures 4 and 5) were rather inconspicuous, more palpable than visible, about 2-3 $\mathrm{mm}$ wide. Generally, all lesions were skin colored, flat or mildly depressed with filiform

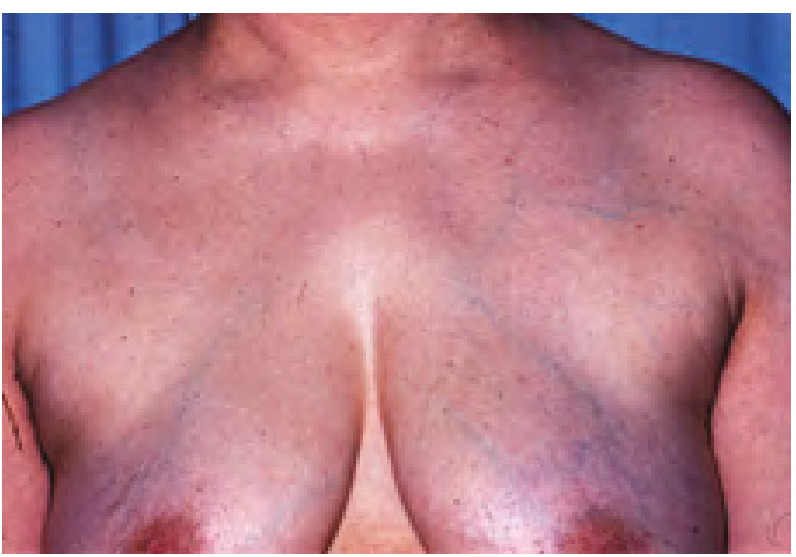

Figure 2. Lesions of the trunk in 1990

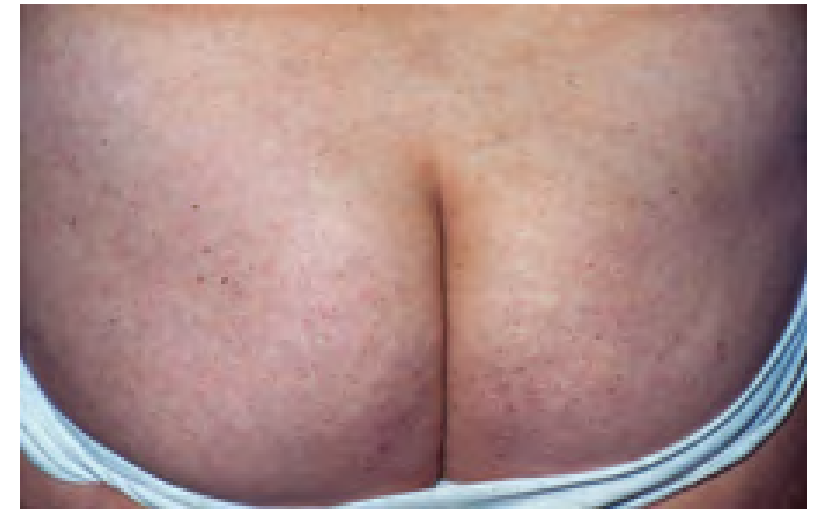

Figure 3. Lesions in the sacral region in 1990 


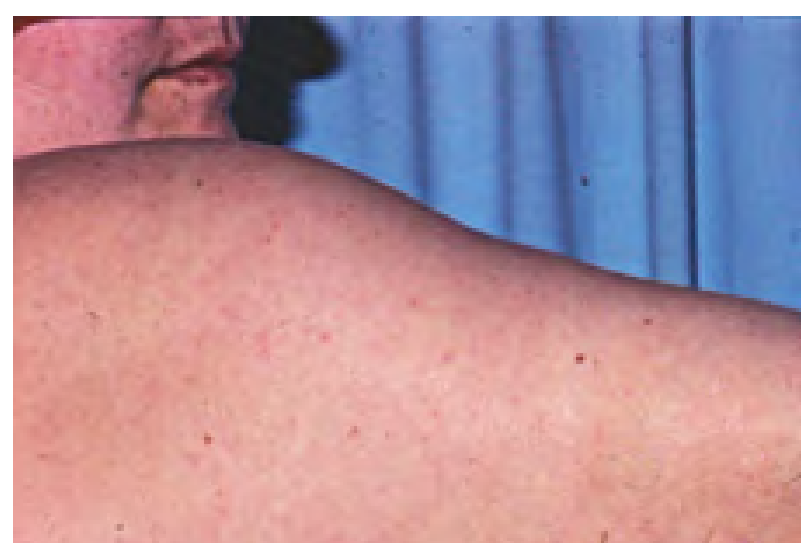

Figure 4. Lesions on the extensor surface of the upper arms in 1990

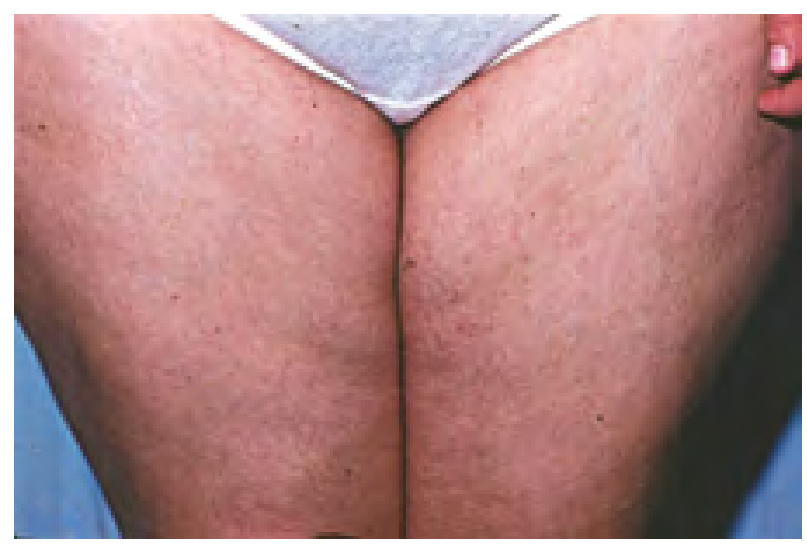

Figure 5. Lesions on the anterior thighs in 1990

cornoid lamella. No changes on the palms or soles were registered.

Current skin condition: dark pigmented circular lesions with atrophic center and keratotic ridge are present on the face (Figure 6) and the whole body (Figures 7 and 8); similar lesions affected the extremities (Figures 9 and 10), dorsal aspects of hands and both thenar and hypothenar sites as well. Hyperkeratosis, rhagades and erythema were present on palms and soles (Figures 11 and 12).

All relevant laboratory tests were within normal limits.

Histopathological analysis revealed features typical of porokeratosis, including cornoid lamella, irregular distribution of keratinocytes in the spinous layer, and lymphocyte perivascular infiltrates in the dermis (Figure 13).

Dermoscopy showed round structures in the form of a "white line" along the edge of each porokeratosis lesion, which is a characteristic

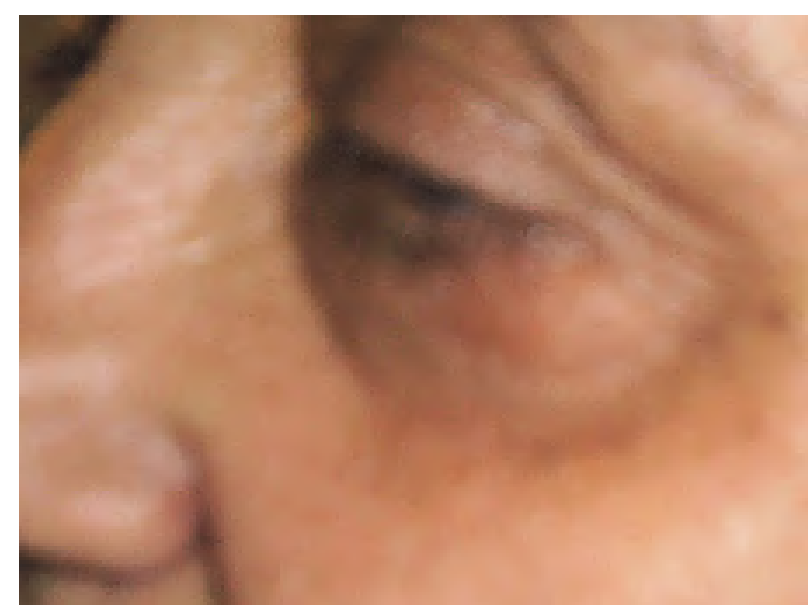

Figure 6. Facial lesions in 2013

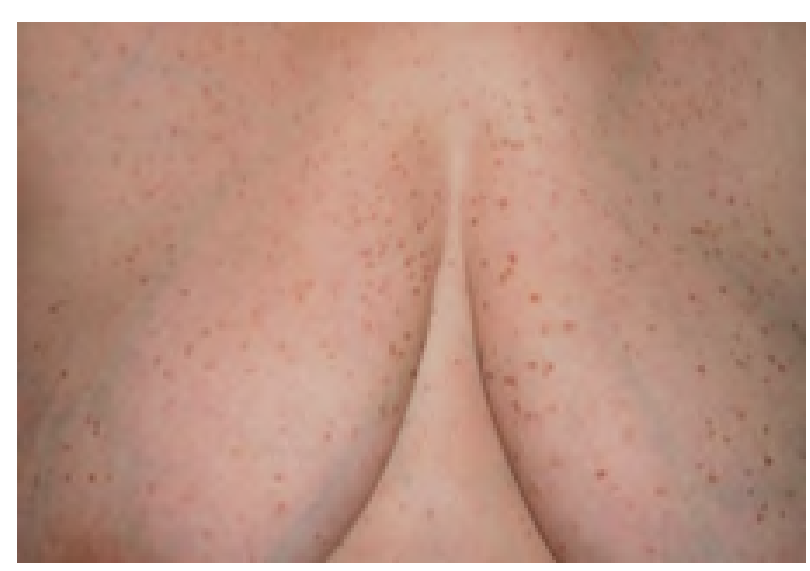

Figure 7. Lesions of the trunk in 2013

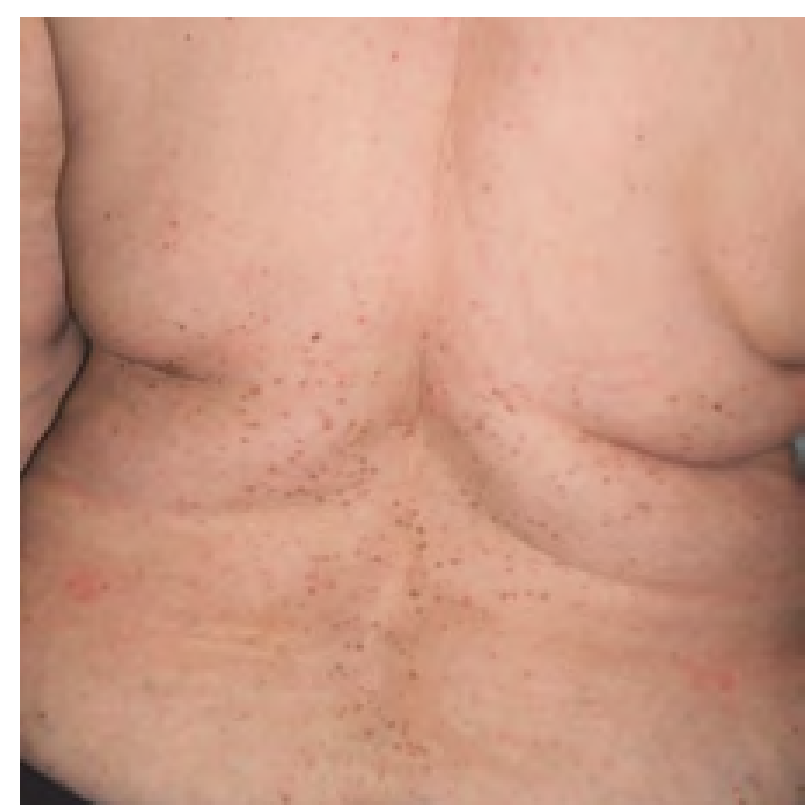

Figure 8. Lesions in the sacral region in 2013 


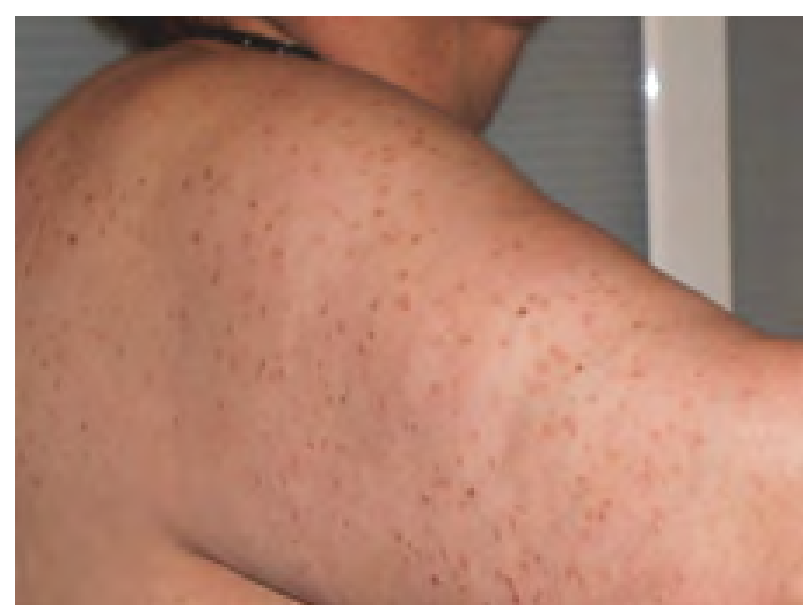

Figure 9. Lesions on the extensor surface of the upper arms in 2013

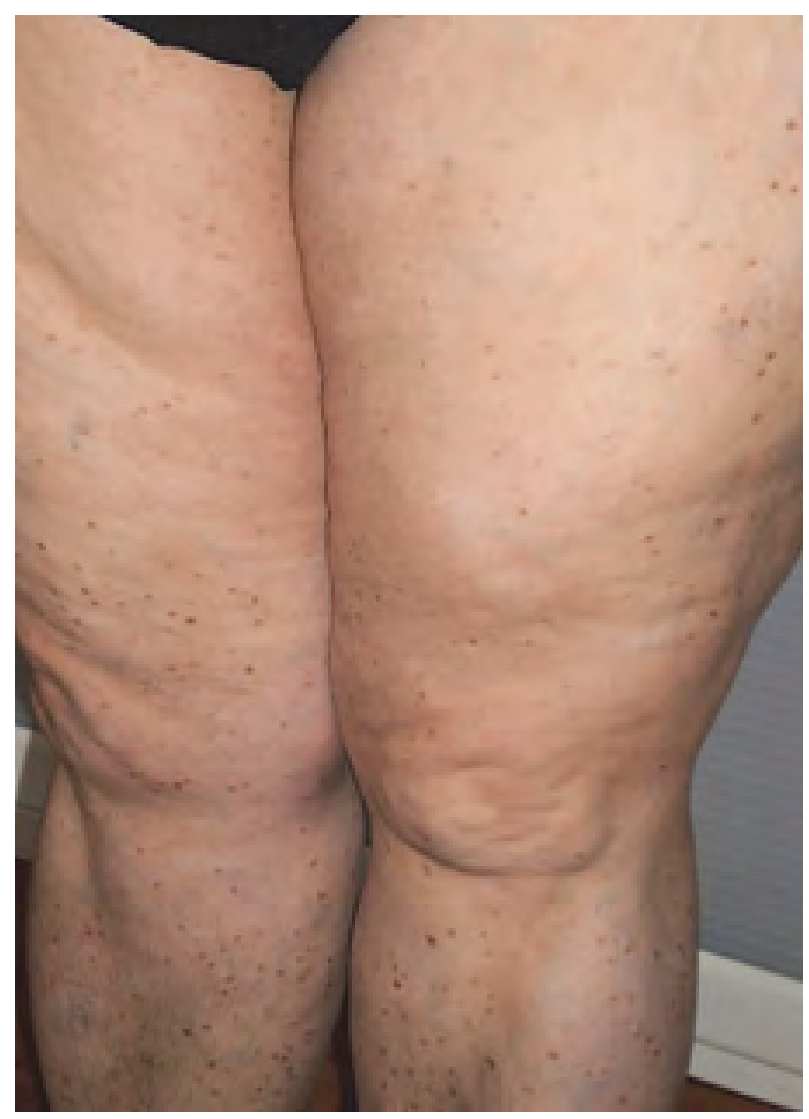

Figure 10. Lesions on the anterior thighs in 2013

dermoscopy view of porokeratosis. They were identified at the periphery of the lesion along with brown pigmentation (globules and red spots) on the inside, and a double "white line" in some parts of the lesion. Structures of a single or double "white

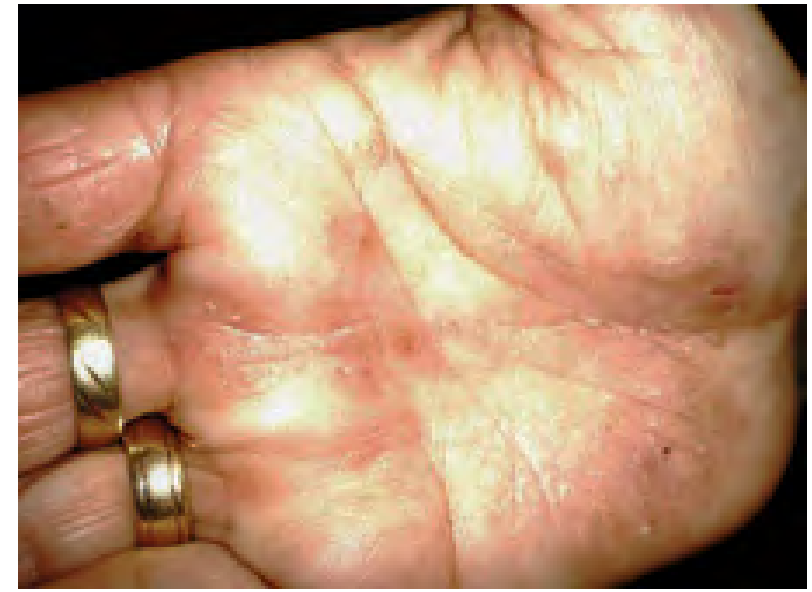

Figure 11. Palmar lesions in 2013

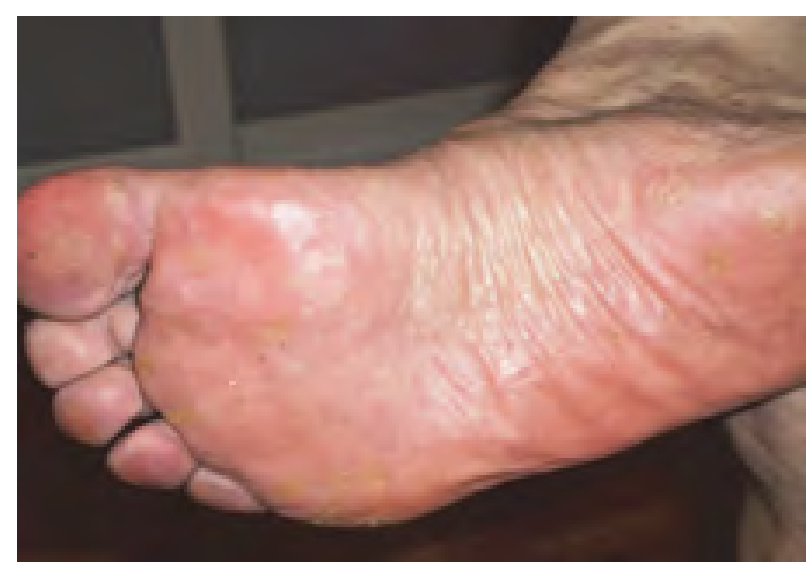

Figure 12. Plantar lesions in 2013

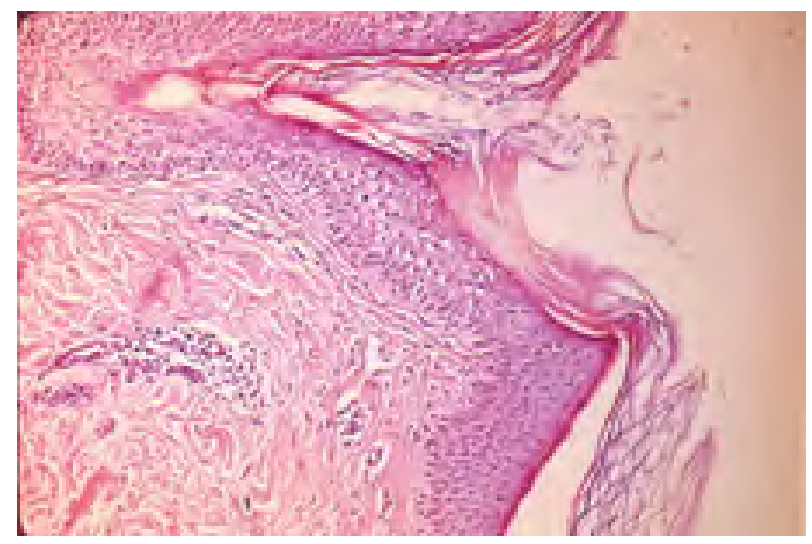

Figure 13. Histopathological findings

line" matched histologically the cornoid lamella and the red spots and globules the enlarged blood vessels (Figures 14 and 15).

Gentian violet staining was positive showing a marked violet staining of the edge of lesion (Figure 16). 


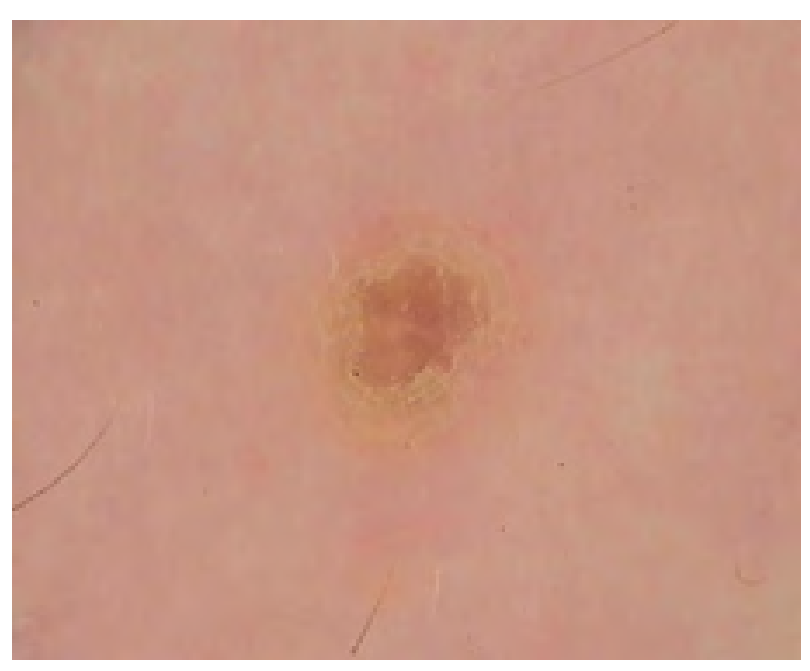

Figure 14. Dermoscopic finding

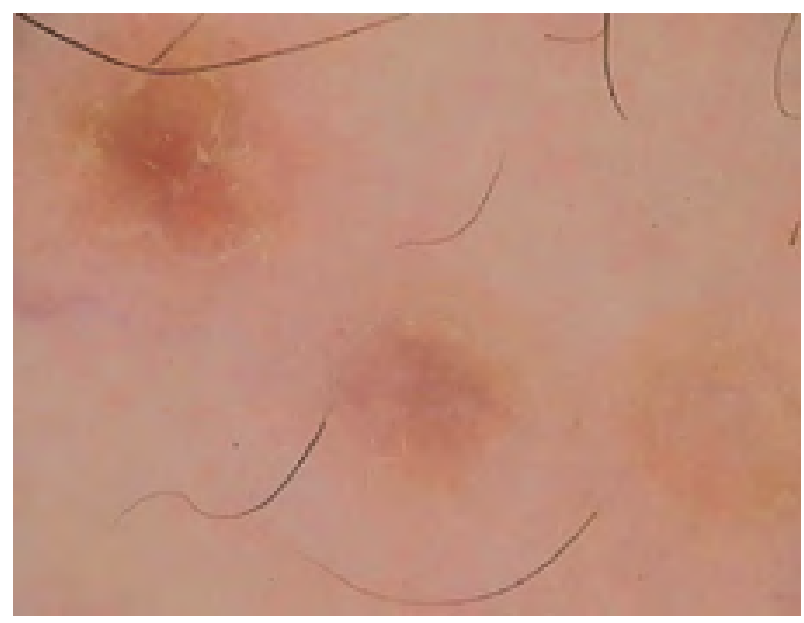

Figure 15. Dermoscopic findings

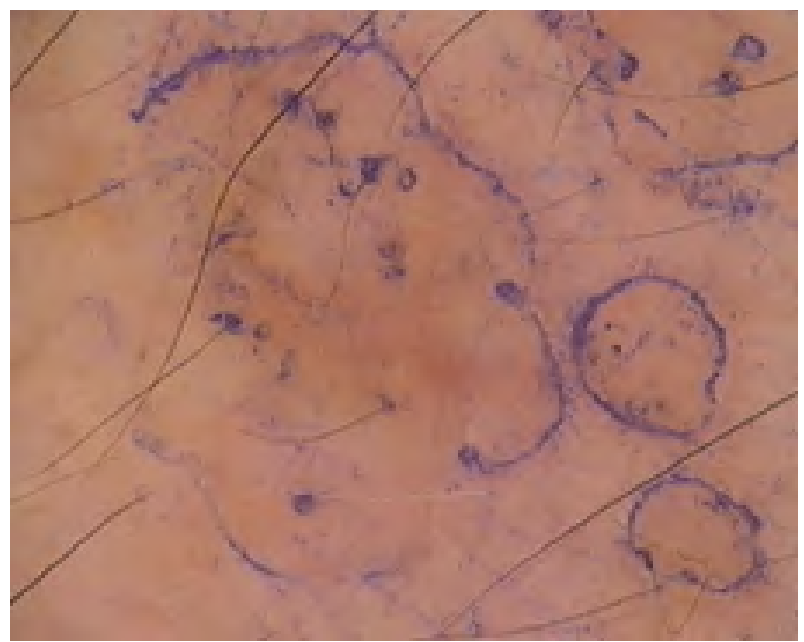

Figure 16. Gentian-violet staining
The patient had no complaints or any subjective symptoms, and she no longer worried about the lesions, not even for esthetic reasons. She was advised to avoid sun exposure, to use photoprotective sunscreens, and topical corticosteroids on the hands.

\section{Discussion}

The etiology and pathogenesis of porokeratosis have not been fully elucidated (14). An autosomal mode of inheritance with variable penetrance has been fairly well established for PM, DPPP, DSP and DSAP (15). Numerous genetic alterations have been indentified, and sometimes even p53 gene expression was altered (16). It is suggested that some clones of epidermal cells were inherited as mutants, the phenotype expression of which resulted from activation by exogenous trigger factors (14).

So far, 4 loci have been established for DSAP (DSAP1, DSAP2, DSAP3, DSAP4), one locus for PPPD and one for DSP $(12,17,18)$, but a porokeratosis gene has not been identified (15). A pathological clone is present in a latent state, and some factors trigger its activation (18). Some predisposing and/or trigger factors have been identified for the development of porokeratosis: genetic predisposition, UV radiation, infectious agents, mechanical trauma and immunosuppression (due to therapy/transplantation) $(10,14,19-24)$.

In the elderly (aged 70 to 90) the trigger factor, apart from UV radiation, can be age-related decreased immunocompetence (2). Diabetes mellitus may be associated with deterioration of immune competence of the elderly (18). It has even been suggested to classify porokeratosis as a subtype of DSAP in old population (2). In rare instances the following trigger factors have also been reported: anti-diabetic and antihypertensive medications, thiazides and antibiotics (2). Co-localization of $\mathrm{P}$ with other dermatoses, i.e. Lichen planus, is explained by isomorphic (Koebner) phenomenon, by some authors $(25,26)$.

Sporadic cases of DSAP (24) have been reported, as subsiding following topical application of $5 \%$ imiquimod or discontinuation of immunosuppressive medication.

DSAP is more or less frequently associated with other types of porokeratosis: DSAP with LP 
and veruccous $\mathrm{P}$ (6); DSAP with warty $\mathrm{P}$ (29); DSAP with giant $\mathrm{P}$ (30), DSAP with LP and PP (31). Coexistence of LP and DSAP has also been reported (32-36). It has been suggested that simultaneous expression of two different genes due to loss of heterozygosity is responsible for coexsistence of various types of porokeratosis (37, 38). Squamous cell carcinoma may arise from lesions of porokeratosis; cases of basal cell carcinoma and Bowen's disease have also been described; malignant alterations have been reported in PM, LP, PPPP and DSP (39), and they are most common in LP. In patients with DSAP, squamous cell carcinoma is rare $(40,41)$. The prevalence of $19 \%$ and $3.4 \%$ has been reported in PL and DSAP, respectively (42). Porokeratosis is a genodermatosis with an increased malignant potential. The risk of malignant alterations is higher in wide, long-standing lesions and in elderly patients.

The diagnosis of DSAP is established based on clinical presentation, personal and family medical history, pathohistological findings, auxiliary methods such as dermoscopy $(43,44)$ and cornoid lamella staining with Gentian violet or toluidine blue to make it more visible $(45,46)$.

An important risk factor for the development of DSAP is chronic or occasional intensive sun exposure, or artificial UV irradiation (22). Our patient developed initial skin changes at the age of 30 , on photo-exposed skin particularly the face, but later on, lesions progressed and affected nonexposed parts of the body, as well.

Her medical history revealed a significant deterioration after sunbathing and time spent at the seaside. The family history was, however, positive. DSAP occurred in three generations: herself, her mother and her daughter. The medical history of our patient suggests that DSAP occurred at the time when she was completely healthy, so effects of other triggers are ruled out.

Based on clinical examination and histopathological findings, differential diagnosis of porokeratosis included: actinic keratosis, psoriasis, lichen nitidus, hereditary punctate keratoderma, benign hamartoma of eccrine sudoriferous glands $(10,47)$.
In the available literature, we found only one report on palmar and plantar involvement in DSAP (31). In children's type of DSP, cases of DPPP have been reported. Can lesions on the hands and feet in our patient be explained as a pure coincidence of DSAP and PPPD, or can they be a part of DSAP?

DSAP usually has a poor therapeutic response to various treatment modalities (43). The course of the disease is progressive with potential malignant alterations. Topical treatment includes: salicylic acid, glycocorticoids, 5-fluorouracil, and retinoids for all types of the disease; $5 \%$ imiquimod cream is used in the treatment of PM, DPPP and genital P; vitamin D3 analogues for DSAP; and $3 \%$ diclofenac gel for DSAP and genital P. In systemic therapy, retinoids are highly recommended in the treatment of all types of $\mathrm{P}$; photodynamic therapy in combination with CO2 laser for DSPA; surgical options include cryotherapy, electrocautery and curettage for small lesions; dermoabrasion for LP; ultrasound surgical aspiration for genital $\mathrm{P}$; total excision for all types of $\mathrm{P}$. Cryotherapy may yield positive results in localized forms such as LP (48). Sun protection is obligatory, as well as long follow-up of each patient in order to detect potential malignant alterations.

\section{Conclusion}

This is a case report of disseminated superficial actinic porokeratosis with a family history in three generations. The patient presented in this report developed lesions on palms and soles as well. As far as the available literature is concerned, this is the second case report of disseminated superficial actinic porokeratosis with palmoplatar involvement.

\section{Abbreviations}

DSAP - Disseminated superficial actinic

porokeratosis

P - Porokeratosis

PM - Porokeratosis of Mibelli

LP - Linear porokeratosis

DSP - Disseminated superficial porokeratosis

DPPP - Disseminated palmoplantar

porokeratosis

PPPP - Punctate palmoplantar porokeratosis

UV - Ultra violet

$\mathrm{CO} 2$ - Carbon dioxide 


\section{References}

1. Freyschmidt-Paul P, Hoffman R, König A, Happle R. Linear porokeratosis superimposed on disseminated superficial actinic porokeratosis: report of two cases exemplifying the concept of type 2 segmental manifestation of autosomal dominant skin disorders. J Am Acad Dermatol 1999;41(4):644-7.

2. Khaled A, Kourda M, Abdelmoula, M'ssedi L, Tougourti MN, Kamoun MR. Late-onset disseminated superficial actinic porokeratosis in an elderly woman. Dermatol Ther (Heidelb) 2011;1(1):15-9.

3. Mibelli V. Contribute allo studio della ipercheratosi dei canali sudoriferi (porocheratosis). G Ital Mal Ven 1893;28:313-55.

4. Shumack SP, Commens C. Disseminated superficial actinic porokeratosis: a clinical study. J Am Acad Dermatol 1989;20:1015-22.

5. McKusick VA. Mendelian inheritance in man: a catalog of human genes and genetic disorders. 12th ed. Baltimore: Johns Hopkins University Press; 1998. p. 1483-4.

6. Murase J, Gilliam AC. Disseminated superficial actinic porokeratosis co-existing with linear and verrucous porokeratosis in an elderly woman: update on the genetics and clinical expression of porokeratosis. J Am Acad Dermatol 2010;63:886-91.

7. Noborio R, Morita A. Split-face trial of CO2 laser-induced ring abrasion and high-dose tacalcitol in the treatment of disseminated superficial actinic porokeratosis. J Dermatol 2012;39:879-80.

8. Tallon B, Blumental G, Bhawan J. Porokeratosis ptychotropica: a lesser-known variant. Clin Exp Dermatol 2009;34:e895-7.

9. McGuigan K, Shurman D, Campanelli C, Lee JB. Porokeratosis ptychotropica: a clinically distinct variant of porokeratosis. J Am Acad Dermatol 2009;60(3):501-3.

10. Sertznig P, von Felbert V, Megahed M. Porokeratosis: present concepts. J Eur Acad Dermatol Venereol 2012;26:404-12.

11. Chernosky ME, Freeman RG. Disseminated superficial actinic porokeratosis (DSAP). Arch Dermatol 1967;96:61124.

12. Liu P, Zhang S, Yao Q, Liu X, Wang X, Huang C, et al. Identification of a genetic locus for autosomal dominant disseminated superficial actinic porokeratosis on chromosome 1p31.3-p31.1. Hum Genet 2008;123:507-13.

13. Paravina M, Jovanović S, Ranđelović J, Stanojević M. Porokeratose disseminée superficielle actinique. Journées Dermatologiques de Paris. Paris: Société francaise de dermatologie; 1990.

14. Terranova M, Amato L, Massi D, Fabbri P. Disseminated superficial actinic porokeratosis in a patient with Sjögren syndrome. Skinmed 2003;2(6):390-1.

15. Cao HM, Wang ZY, Zhang GW, Liu CF, Pan CM, Zhao $S X$, et al. Identification of a locus (DSP2) for disseminated superficial porokeratosis at chromosome 12q21.2-24.21. Clin Exp Dermatol 2012;37:672-6.

16. Ninomiya Y, Urano Y, Yoshimoto K, Iwahana H, Sasaki S, Arase $\mathrm{S}$, et al. p53 gene mutation analysis in porokeratosis and porokeratosis-associated squamous cell carcinoma. J Dermatol Sci 1997;14:173-8.
17. Xia JH, Yang YF, Deng H, TangBS, Tang DS, HE YG, et al. Identification of a locus for disseminated superficial actinic porokeratosis at chromosome 12q23.2-24.1. J Invest Dermatol 2000;114:1071-4.

18. Patrizi A, D’Acunto C, Passarini B, Neri I. Porokeratosis in the elderly: a new subtype of disseminated superficial actinic porokeratosis. Acta Derm Venerol 2000;80:302-4.

19. Kanitakis J, Euvrard S, Faure M, Claudy A. Porokeratosis and immunosuppression. Eur J Dermatol 1998;8:459-65.

20. Cha SH, Park HT, Lee JY, Cho BK. Atypical porokeratosis developing following bone marrow transplantation in a patient with myelodysplastic syndrome. Ann Dermatol 2010;22:206-8.

21. O’Donnell BP, Dawson NA, Weiss RB,Myers CE, James WD. Suramin-induced skin reactions. Arch Dermatol 1992;128:75-9.

22. Kawara S, Oiso N, Kawada A. Disseminated superficial actinic porokeratosis in a patient undergoing treatment wih long-term narrowband ultraviolet B for psoriasis. J Dermatol 2011;38:585-7.

23. Stewart L, Howat A, Coulson I. Disseminated superficial porokeratosis secondary to immunosuppression induced by etanercept for extensivw psoriasis. Arch Dermatol 2010;146:1193-4.

24. Buhl T, Wienrich BG, Sieblist C et Schon MP, Zeitz CS. Development of segmental superficial actinic porokeratosis during immunosuppressive therapy for pemphigus vulgaris. Acta Derm Venereol 2010;90:212-3.

25. Ghosh SK, Bandyopadhyay D, Chatterjee G, Ghosh AP. Co-localization of lichen planus and porokeratosis of Mibelli. Indian J Dermatol Venereol Leprol 2009;75: 532-4.

26. Golchai J, Ramezanpour A. Report of new case with four skin diseases. Dematol Online J 2003;9:15.

27. Goulding JM, Teoh JK, Carr RA, Humphreys F, Gee BC. Eruptive disseminated superficial porokeratosis with rapid resolution: a drug-induced phenomenon? Clin Exp Dermatol 2009;34:895-7.

28. Hwang SM, Choi EH, Ahn SK. Disseminated superficial actinic porokeratosis like drug eruption: a case report. J Korean Med Sci 1999;14:227-9.

29. Kanak K, Jaiswal AK, Reddy P. Disseminated superficial and warty type of porokeratosis: a rare coexistence. Indian J Dermatol 2011;56(5):576-7.

30. Hanumanthayya K, Magavi S, Tophakhane R, Rathod $\mathrm{R}$, Coexistence of disseminated superficial and giant porokeratosis of Mibelli with squamous cell carcinoma. Indian J Dermatol Venereol Leprol 2003;69:296-9.

31. Gautam RK, Bedi GK, Schgal VN, Singh N. Simultaneous occurrence of disseminated superficial actinic porokeratosis (DSAP), linear, and punctate porokeratosis Int J Dermatol, 1995;34:71-2.

32. Freyschmidt-Paul P, Hoffmann R, König A, Happle R. Linear porokeratosis superimposed on disseminated superficial actinic porokeratosis: report of two cases exemplifying the concept of type 2 segmental manifestation of autosomal dominant skin disorders. J Am Acad Dermatol 1999;41:644-7.

33. Suárez-Amor O, Pereiro-Ferreirós M, Ginarte M, Peteiro C, Toribio J. Coexistence of linear porokeratosis and 
disseminated superficial actinic porokeratosis: a type 2 segmental manifestation. Acta Derm Venereol 2007; 87:363-4.

34. Kaur S, Thami GP, Mohan H, Kanwar AJ. Co-existance of variants of porokeratosis: a case report and a review of the literature. J Dermatol 2002;29(5):305-9.

35. Boente MdelC, Lopez-Baro AM, Frontini MdelV, Asial RA. Linear porokeratosis associated with disseminated superficial actinic porokeratosis: a new example of type II segmental involvement. Pediatr Dermatol 2003;20(6):514-8.

36. Pearson IC, Cliff S. Clinicopathological cases: case 6. Clin Exp Dermatol 2003;28:345-6.

37. Happl R. A rule concerning the segmental manifestation of autosomal dominant skin disorders: review of clinical examples providing evidence for dichotomous types of severity. Arch Dermatol 1997;133:1505-9.

38. Dover JS, Phillips TJ, Bums DA, Krafshik B. Disseminated superficial actinic porokeratosis coexistence with other porokeratotic variants. Arh Dermatol 1986;122(8):887-9.

39. Leache A, Soto de Delás J, Vázquez Doval J, Lozano MD, Quintanilla E. Squamous cell carcinoma arising from a lesion of disseminated superficial actinic porokeratosis. Clin Exp Dermatol 1991;16:460-2.

40. Lee HR, Han TY, Son SJ, Lee JH. Squamous cell carcinoma developing with in lesions of disseminated superficial actinic porokeratosis. Ann Dermatol 2011;23(4):536-8.

41. Chernosky ME, Rapini RP. Squamous cell carcinoma in lesions of disseminated superficial actinic porokeratosis: a report of two cases. Arch Dermatol 1986;122:853-5.

42. Sasson M, Krain AD. Porokeratosis and cutaneous malignancy. Dermatol Surg 1996;22:339-42.

43. Kim HS, BaekJH, Park YM, Kim HO, Lee JY. Photodynamic therapy combined with $\mathrm{CO}_{2}$ laser, vaporization on disseminated superficial actinic porokeratosis: a report of 2 cases on the face. Ann Dermatol 2011;23(Suppl 2):211-3.

44. Zabbalos P, Puig S, Malvehy J. Dermoscopy of disseminated superficial actinic porokeratosis. Arch Dermatol 2004;140:1410.

45. Thomas CJ, Elston DM. Medical pearl: gentian violet to highlight the cornoid lamella in disseminated superficial actinic porokeratosis. J Am Acad Dermatol 2005;52(3 Pt1):513-4.

46. Dongre A, Adhe V, Sanghavi S. Genital porokeratosis: a rare entity. Indian J Dermatol 2013;58:81-3.

47. Rouhani P, Fischer M, Meehan S, Pomeranz MK. Disseminated superficial actinic porokeratosis. Dermatol Online J 2012;18(12):24.

48. Stojanović S, Jovanović $M$, Vučković N, Inkov-Simić $M$, Tasić S. Linear porokeratosis: a case report. Serb J Dermatol Venereol 2012;4(3):105-12.

\section{Diseminovana superficijalna aktinička porokeratoza sa progresivnim tokom: prikaz slučaja u kome se bolest javila u tri generacije iste porodice}

\section{Sažetak}

Uvod: Porokeratoza (P) jeste heterogena grupa genetski determinisanih poremećaja keratinizacije, koju karakterišu kružne lezije sa centralnom atrofijom i perifernim keratotičnim rubom koji histološki odgovara kornoidnoj lameli. Zavisno od veličine, lokalizacije i broja lezija, razlikuje se više podtipova P. Od 1893. godine, kada je Mibeli (Mibelli) opisao porokeratozu koja je po njemu dobila ime, registrovani su novi tipovi, to su: 1 . Mibelijeva porokeratoza (Porokeratosis Mibelli PM); 2. linearna porokeratoza (LP); 3. diseminovana superficijalna porokeratoza (DSP); 4. diseminovana superficijalna aktinička porokeratoza (DSAP); 5. diseminovana palmoplantarna porokeratoza (DPPP); 6. punktatna palmoplantarna porokeratoza (PPPP) i 7. ptihotropna prokeratoza. Takođe se govori o facijalnoj, džinovskoj, retikularnoj, hipertrofičnoj verukoznoj porokeratozi (10). PM,
LP, PPPP su lokalizovane, a DSAP, DSP i DPPP su diseminovane porokeratoze.

Termin diseminovana superficijalna aktinična porokeratoza (DSAP) predložili su Černoski i Friman (Chernosky, Freeman) 1967. godine. To je najčešći oblik porokeratoze; obično se javlja u trećoj ili četvrtoj deceniji života ali, zavisno od uzroka, može nastati i ranije ili kasnije. Češća je kod žena, naročito u oblastima sa dugim periodima insolacije. Promene su lokalizovane na fotoeksponiranim regijama, ali na licu samo u $15 \%$ slučajeva. Mogu nastati i na fotoneeksponiranim delovima tela. Inicijalne lezije su keratotične papule, a kasnije nastaju naglašene anularne lezije sa atrofičnim centrom i keratotičnim rubom, kornoidnom lamelom koja je karakteristična za sve podtipove porokeratoze.

Prikazujemo slučaj bolesnice sa izraženom slikom 
DSAP koja je prve promene na koži dobila pre 27 godina, a 1990. godine, slučaj ove bolesnice i njene majke prikazan je na Dermatološkim danima u Parizu.

Prikaz bolesnika: Bolesnica, 57 godina, medicinska sestra u penziji, bavi se i poljoprivredom.

Prve promene na koži lica javile su joj se u 30. godini života. Naredne godine, posle sunčanja i boravka na moru, promene su se javile na ekstenzornim stranama nadlaktica i podlakica i na potkolenicama. Tada su bile više palpabilne nego vidljive. Narednih godina javljale su se nove lezije veličine $2-5 \mathrm{~mm}$. $\mathrm{U}$ to vreme nije bolovala od drugih bolesti. Tokom 2001. godine imala je hepatitis B, potom se kod nje razvila artroza oba zgloba kuka i dobila je povišen krvni pritisak. Majka je imala istu bolest kože, a ćerka tačkaste tamnije fleke oko usana.

U radu je uporedo prikazano stanje na koži 1990. i 2013. godine prilikom poslednjeg pregleda. Stanje na koži 1990. godine: promene na licu u vidu mrlja veličine $2-3 \mathrm{~mm}$, hiperpigmentovane na periferiji i svetlije u centru, teško estetski prihvatljive; na trupu i ekstremitetima promene diskretne, više palpabilne nego vidljive $2-3 \mathrm{~mm}$ u prečniku, ravne ili lako deprimirane površine sa filiformnom kornoidnom ivicom klinički nepromenjene boje kože; promene na dlanovima i tabanima nisu registrovane.

Sadašnje stanje (2013. godina): na licu i čitavom telu tamnopigmentovane kružne lezije atrofičnog centra sa keratotičnom ivicom, promene istih osobina na ekstremitetima dorzumima šaka, tenaru i hipotenaru; na ostaloj koži šaka hiperkeratotične naslage, ragade i eritem; na tabanima blaga hiperkeratoza i eritem.

Svi rezultati osnovnih laboratorijskih analiza bili su u granicama referentnih vrednosti.

Patohistološka analiza bioptiranog uzorka promene na koži potvrdila je dijagnozu nalazom karakterističnim za porokeratozu, uključujući i kornoidnu lamelu, nepravilno raspoređene keratinocite u spinoznom sloju i limfocitni perivaskularni infiltrat u dermisu.

Dermoskopski pregled (struktura tzv. „belog traga" prisutna na periferiji lezije sa braonkastom pigmentacijom prema centralnim delovima lezije i sa dvostrukom strukturom tipa „duplog belog traga" na pojedinim delovima promene; crvene tačke i globule (krvni sudovi u centralnim delovima) i bojenje gencijanom violet (izrazita ljubičasta prebojenost rožaste ivice), kao pomoćne dijagnostičke metode, takođe su potvrdile dijagnozu porokeratoze.

U terapiji je savetovano izbegavanje izlaganja suncu i primena fotoprotektivnih krema, a za promene na koži naročito na šakama kortikosteridne masti.

Diskusija: Etiologija i patogeneza porokeratoze nisu potpuno razjašnjene. Autozomalni način nasleđivanja sa varijabilnom penetracijom je dosta dobro utvrđen za pojedine tipove porokeratoze : PM, DPP, DSP,DSAP. Pokazalo se da su neki klonovi epidermalnih ćelija nasleđeni kao mutant, čija je fenotipska ekspresija rezultat aktivacija egzogenih okidačkih faktora.

Značajan faktor za nastank DSAP je hronično ili povremeno intezivno izlaganje sunčevoj svetlosti ili veštačkim izvorima sunčevih zraka. Naša bolesnica je prve promene dobila na licu u 30. godini života, zatim na fotoeksponiranim, pa progresivno i na fotoneeksponiranim delovima tela. U anamnezi ima podatak o značajnom pogoršanju posle sunčanja i boravka na moru. DSAP može biti udružen sa ostalim tipovima: DSAP sa LP i verukoznom P; DSAP sa verukoznom P; DSAP sa gigantskom $P$, DSAP sa LP i PP. Koegzistencija LP i DSAP takođe je opisana.

Porokeratoza se smatra prekursorom za spinocelularni karcinom kože, a opisana je i pojava bazocelualrnog karcinoma i Bovenove (Bowen) bolesti. Kod bolesnika sa DSAP spinocelularni karcinom nastaje ređe u odnosu na LP (3,4 : 19\%). Oboleli sa DSAP obično pokazuju slab terapijski odgovor na različite modalitete tretmana. $\mathrm{Za}$ topikalnu primenu koriste se salicilna kiselina, glikokortikoidi, 5-fluorouracil, analozi vitamina D3, diklofenak gel (3\%); za sistemsku primenu koriste se retinoidi, a za fizikalnu fotodinamička terapija, eventualno $\mathrm{CO}_{2}$ laser. Kod lokalizovanih formi, mogla bi se koristiti krioterapija koja je dala dobre rezultate kod linearne porokeratoze. Obavezno se savetuje zaštita od sunca i praćenje bolesnika, uz adekvatan tretman u slučaju eventualne maligne alteracije.

Zaključak: Prikazan je slučaj diseminovane superficijalne aktiničke porokeratoze s porodičnim 
javljanjem u tri različite generacije. Kod obolele literaturi, ovo predstavlja drugi opisani slučaj osobe prikazane u ovom radu, bolest je zahvatila diseminovane superficijalne aktiničke porokeratoze i kožu šaka i stopala. Prema nama dostupnoj sa palmoplantarnim promenama.

\section{Ključne reči}

Porokeratoza + genetika; Aktinična keratoza; Palmoplantarna keratoderma; Tok bolesti; Faktori rizika 